\title{
Community Leader in Enhancing Rural Economic Growth in State of Terengganu, Malaysia
}

\author{
Aizuddin Md Rami, Hafis Simin, Ramle Abdullah, Abdullah Ibrahim
}

\begin{abstract}
Community-based tourism products have the potential to be featured as a new product to attract foreign tourists in knowing the benefits of community-based products in rural areas. Community-based tourism is seen as a sustainable tourism that can help rural community members improve their standard of living without damaging the environment. Terengganu is one of the most famous landmarks of nature tourism, culture and history. The purpose of study to exploring how local leader enhance their community economic growth. The data of study was captured using interview among 26 rural entrepreneurs who are operating their business in the selected 4 villages. The study has successfully analyzed the contribution played by the local leader leaders as a rural community leader in helping to highlight the potential of community-based tourism products, and indirectly encourages business and economic growth of rural people in the state of Terengganu, Malaysia. Therefore, federal and state government can take this finding as guidance as well as to construct the rural entrepreneurship in implementing the rural entrepreneurship development.
\end{abstract}

Keywords: Community leadership, economic, leader strategies, rural tourism.

\section{INTRODUCTION}

Rural community-based tourism has contributed significantly to the country's economic development and also helped in tourism industry products development in Malaysia. In fact, the tourism sector is a sector that contributes nearly $14.9 \%$ of the national income [7] and provides over 1.7 million jobs in the country. Based on reports from Tourism Malaysia, The Ministry of Tourism Malaysia, nearly 82.1 billion Ringgit has been generated as a result of income from tourism sources in 2018, which are partly generated by community-based tourism products in rural areas. In the state of Terengganu, tourism sector has become as local's economic heart. Based on Terengganu's MOTAC report [15], tourist (domestic and international) arrivals statistics to Terengganu, are showing a consistent increment each year (Table 1). From 2012 to 2017, about 22 million tourists visited the state, by becoming the second contributor of state revenue. Consequently, the annual growth in tourism growth was impressive at $17.21 \%$ over the last 5 years. To strengthen the tourism sector in Terengganu, the state government is actively promoting various cultural and environmental tourism attractions.

Revised Version Manuscript Received on September 16, 2019. Aizuddin Md Rami, Universiti Sultan Zainal Abidin, Malaysia.

Hafis Amat Simin, Universiti Sultan Zainal Abidin, Malaysia.

Ramle Abdullah, Universiti Sultan Zainal Abidin, Malaysia.

Abdullah Ibrahim, Universiti Sultan Zainal Abidin, Malaysia.
Table 1: Statistics of tourist arrivals to Terengganu (2012-2017) [14]

\begin{tabular}{|c|c|}
\hline Year & Tourist Arrivals to Terengganu \\
\hline 2012 & $3,376,275$ \\
\hline 2013 & $4,037,130$ \\
\hline 2014 & $4,517,781$ \\
\hline 2015 & $4,731,694$ \\
\hline 2016 & $4,904,669$ \\
\hline 2017 & $4,950,768$ \\
\hline
\end{tabular}

Terengganu is a state which located in Malaysia's east coast, and also famous with its nature-based tourism attractions such as islands, lakes, and mountains. In fact, the state is also rich with community products and identities such as traditional games, craftsmanship, food, traditional culture and also Islamic culture. One of the cultural attractions that can be reinforced as one of community-based tourism is through Malays' local knowledge, which known as the major majority residents in Terengganu. In addition, the involvement of rural community in tourism activities is one of the development strategies that can be implemented in order to change the fate and standard of living which often being labeled as poor, retiring, and marginalized from development flows. According to [18], the tourism industry is an economic sector that has good prospects, especially in attractive locations such as island which still having least developed villages on it. Furthermore, most tourists prefer discovering reality and originality in a tourism destination, especially in the context of environmental and unpolluted cultures [12], [17].

Hence, rural tourism become major roles in the development of local socioeconomics. These include the provision of jobseeker, maximum use of lading, gardens and land, promoting local food, and promoting homestay, chalet in the interior [6]. On the other hand, developments in the tourism sector in rural areas have indirect impacts on other sectors too, which unintentionally has strengthened the transportation networks, services, and infrastructure that serve a great contribution to community residents [13] According to [1], in order to ensure that tourism in rural areas is well-managed, the role of local leaders is indispensable in assisting their communities through planning and developing local tourism products. Additionally, in [2] explain the need 
of effective leadership in driving the development of tourism and leadership must be collaborated with a comprehensive involvement of community members in order to pursuit any desire.

Similarly, in [11] finds that a sense of leadership that identifies the need of taking calculated risks can lead to tremendous change which is essential to destination's development, as that has been signified as a skill to form effective collaborations and partnerships with other stakeholders in the system. Whilst most rural communities possess fledgling leaders, external facilitators are often required to coordinate rural tourism development plans within a destination and the success is typically attributed to the leadership effectiveness. In fact, the issue is not just the role that local leaders play, but the role of followers in making every plan and direction that their leaders have given is also very important. Their compliance with the leaders makes every development plan easier to do. In addition, role of leaders and followers in the context of rural tourism is a must-have journey [20] that ensures that they achieve the desired goals. This study will analyze the role of the Villages Development and Safety Committee (MPKK); the local community leader who has been appointed officially by the government in providing assistance and support rural tourism businesses and promotes followership would be acting as a coordinating force for rural tourism development in order to enhance and sustain the local economy. The aim of this paper is to develop insights and enhance understanding of leadership and followership in rural tourism destinations.

\section{LITERATURE REVIEW}

According to [5], community-based tourism is a community empowerment and ownership, conservation of natural resources, culture, social and economic development as well as the quality of visitor experience (satisfaction level). Community-based tourism is aimed by achieving sustainable development for the outer community. The city community can improve their standard of living without damaging the environment while still having opportunities to improve the economic outcomes of tourism activities, as well as increasing their knowledge and experience. The sense of understanding and appreciation of culture, heritage, and values are held by the locals themselves [9]. Hence, the need for clear research to develop community participation, redistribution of authority, cooperation process as well as social capital is important [10]. In [3] describe community-based tourism as a method of development by referring to community participation approach. This approach involves cultural development and conservation. In addition, there are some positive and beneficial features of community-based tourism which covering economic, environmental, and socio-cultural aspects.

According to [5], community-based tourism plays an important role in the development of rural communities. Community-based tourism refers to tourism activities and services developed by local community members or private sector and non-governmental partnerships. Generally, community-based tourism is based on special elements in the community's life, culture, and nature. In [18] describes the community as referring to some of the key elements, namely humanity, living space, social interaction, collaborative spirit, and collective identification (identifiable characteristics). Through tourism industry, this can help in developing area and community, especially the outskirts and suburbs such as job opportunities and economic activities. Tourism development, in fact, improves the quality of local physical development through a network of basic amenities and facilities that will be enhanced in order to meet the requirements of good quality tourism [8]

In [16] explained a community-based tourism model as the result of two approaches of integration, namely bottom ups and top down approaches in strategic rural community development planning. Almost all community-based tourism products used native products from a variety of sources such as traditional culture, knowledge, heritage food, and natural resources.

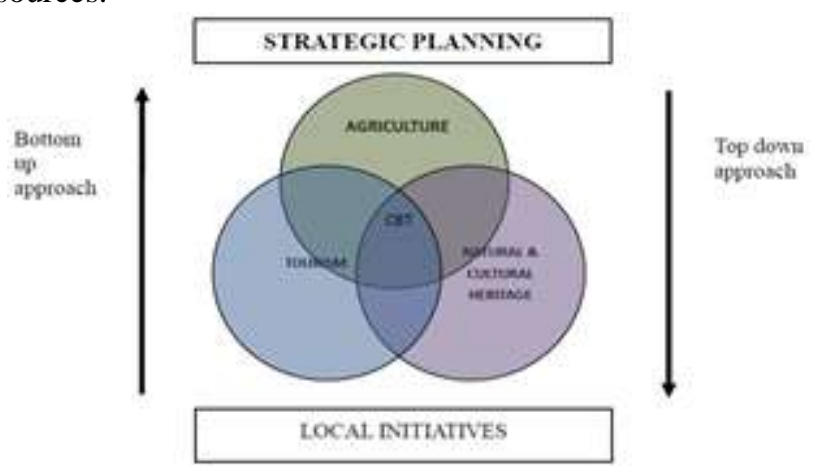

Fig. 1: Community-based tourism model [16]

Integration between the three aspects of tourism, agriculture and cultural heritage is identified as a community development strategy in rural areas (Fig. 1). Development of the tourism sector is a step towards helping the rural community while still being supported by other sectors. As a result of the merger, there is an alternative to assist the upgrading of rural communities, which often been referred as poor, marginalized and backward from the current development [18].

\section{RESEARCH DESIGN}

\section{A. State of Terengganu, Malaysia}

Terengganu State is a state which located on the east coast of peninsular Malaysia and borders of Kelantan and Pahang. The social and cultural structures in the state of Terengganu still remain as a Malay cultural heritage. In fact, the cultural atmosphere in Terengganu is still genuine and well-preserved by the local community. Terengganu is also famous with heritage art such as traditional games, traditional foods, and cultural performances that are still actively practiced in the present. Apart from that, Terengganu is also rich in the beauty of nature-based such as islands, mountains, coastal resorts and villages that still retain the Malay heritage concept. Meanwhile, Terengganu is also a major tourist destination in Malaysia [18]. Not surprisingly, Terengganu is also famous with its tourism concepts which related to nature, culture and community roots. The increasing tourist arrival every year has proven Terengganu as one of high preferable tourism destination among tourists.

Published By:
Blue Eyes Intelligence Engineering

\& Sciences Publication 


\section{B. Villages Development and Safety Committee (MPKK)}

Villages Development and Safety Committee (which also known as MPKK), is a known as local leader appointed officially by the government and local authorities. MPKK is an organization that manages a village in Malaysia. The chairman of the MPKK will be called as village chief. The main function of MPKK chairman and committee member is to plan and implement a village development transformation plan with the involvement of local communities by using a bottom-up approach towards creating a sustainable, competitive and prosperous village. Plus, it also platform in implementing a comprehensive human capital transformation to create a united, progressive society which practicing pure values as well as supporting the foundations of the nation. In fact, they action is needed in order to help the government and local people to improve the social, economic, education, infrastructure, welfare, health and safety of the village.

\section{METHODOLOGY}

The study is conducted in the State of Terengganu by using the qualitative phenomenological research approach which has been employed to address the issues raised in the study. Qualitative methods can help researchers to obtain more accurate data, and create a vivid understanding upon phenomena that occur in the real context [19]. Four excellent communities per village in the state were chosen as the study area. The data is collected from interviews and observations to answers the objective of the study. The use of different data gathering techniques has provides an advantage to this study as various techniques would able to view triangulation analysis even more precisely. In the meantime, interview has been the main method in collecting information from the informants. This technique is used in order to understand the roles of the local leader in promoting followership amongst rural tourism small-scale businesses. Interviews sessions are held with community leaders and the local community which probed on daily activities in local tourism, local based product, and travel agency promoting local attraction. The role of leaders also being used in order to manage the affairs of the community, such as meetings, gatherings and also the relationship between local tourism partner and related external agencies.

In this study, the researchers have identified the appropriate informants to clarify questions. Consequently, a total of 26 rural entrepreneurs, 20 informants comprised of community leaders (MPKK), locals that related to community based tourism and officials in the relevant government agencies are selected. In addition, relevant documents were analysed to obtain further data for analysis. The researchers also evaluated several relevant documents that were considered as appropriate and may be used as evidence. Once the data were collected, analysed and prepared, the data were analysed by using the ATLAS.ti software. The software has helped the researchers to compile, analyze, and make the connection between the themes.

\section{RESULTS AND DISCUSSION}

\section{A. Build networks with stakeholders}

It is important for local leaders to know the potential of products produced by community members that can be featured as tourism products. The proactive role of local leaders such as MPKK chairpersons is important in promoting their area to outsiders. The village committee headed by them (MPKK) should act more courageously in providing materials and tourism products in order to commercialize the brand and help the communities in that particular area. The aid and assistance from local leaders is essential in helping members of their community to grow. One study conducted by [20] has shown that the involvement of local leaders in promoting community-based tourism products can help to strengthen networks and stronger relationships with outsiders including government agencies, private and tourism industry players.

In fact, in [21] stated that the direct involvement of local leaders has known as a succeeded mechanism in increasing the presence of tourists which is also surprisingly capable in-building a comprehensive network with travel service providers. This has given a positive picture of local involvement of local leaders as to be really significant to determine the success of local socioeconomic improvements. Based on this study, Kg. Kayu Kelat has successfully built a whole network with outsiders by strengthening the delivery system as well as promoting their village product with outsiders. Village leadership has provided their village product form and brochure and keep carrying the distributive information while being outside the area regardless while attending a conference, seminar or participating in government programs abroad. Their leaders also regularly participate in tourism product promotion seminars, where most of the seminars are act in preserving the countryside as a tourism product. In fact, the village atmosphere which surrounded by paddy fields and hillside in the Kg. Kayu Kelat area has makes them as to be attractive and informative by tourists to come for a visit, with variety of food products, services such as traditional massage and live cultural activities such as dance performances and Muay Thai serve in the village.

\section{B. 0020Utilise rural areas as an opportunity}

The creativity and openness of local leaders' thoughts and insight are indispensable since they need to see the obstacle as an opportunity. Developing rural areas as a destination for travelers to visit is a real tough effort. However, the ability of a leader to see each space as an opportunity is important in order to ensure that the locals is benefited. In another words, "creating opportunities is important for leaders and benefiting followers". Many literatures related to leadership and followership.

At the site of the study, some local leaders are seen to be able to utilize existing resources such as traditional games like wau games, crockery, food making such as cakes, salted duck eggs, kelapa natal companies and so on. In fact, they have also promoted their area as the best homestay in the state of Terengganu. Local leaders have also registered their area with the Terengganu state tourism agency in order to promote their community-based products. Through the tourism-based tourism industry, it can help the development of an area and 
community, especially the outlying and suburban areas such as job opportunities and economic activities. Tourism development, in fact, improves the quality of local physical development through a network of basic amenities and facilities that will be enhanced to meet the requirements of good tourism [8].

\section{Provide tourism initiative in rural area}

Participation of community leader in rural community development is subjected to the development of various interests to the society itself by involving the community actively. The development was carried out by using the paradigm empowerment which is necessary in order to establish leader's participation in good planning, implementing and controlling development in the countryside, villages, and in the district [4]. At this point, the success of the community-based tourism products marketed is relatively due to the role of the local leader himself who is responsible to lead a tourism-based development project. They are actively participating in promoting their area to tourists as well as outsiders. For example, MPKK Kg. Kayu Kelat uses Facebook as one of the initiatives to promote local tourism products. Similarly, Kg. Banggol Katong uses networks with private parties in a way to distribute their tourism products with tourism related agencies such as homestay and homestay packages. Currently, the MPKK leadership in Kg. Kayu Kelat intends to provide more quality and comfortable village dwellers to foreign tourists such as Australia and Europe, who are the prominent supports for existing programs in their area. This has clearly demonstrates local leadership as a key element in promoting external participation in promoting local awareness activities. At the same time, there is an opportunity in introducing the Malaysian Malay culture to the world.

\section{Implement a tourism development policy}

Tourism is particularly significant to rural area in terms of generating income, as well as job creation, community cohesion, farm diversification and the provision of tourist facilities that improve the quality of life for local communities [20]. However, many rural tourism businesses in Terengganu, Malaysia are small and need help if they are about to contribute to the overall development of a rural being as a challenge for individual businesses. In particular, it is difficult to distinguish between the comparative advantages of rural tourism destinations, hence the need to effectively utilise destination resources to ensure competitive advantage [22] is required. This is where MPKK leaders plays an important role as a transformational leader, as they can develop a more holistic view of village in Terengganu as a coherent destination and are able to identify new ways of developing and promoting natural and cultural assets through a range of projects.

\section{CONCLUSION}

Community-based tourism plays an important role in the development of rural communities from local social and economic aspects. Generally, community-based tourism is implemented by highlighting and promoting special elements in the life of a community, culture and nature of an area. tourism destination, as visualising the bigger picture is often

Through the tourism industry, it can help the development of an area and community, especially the outskirts and suburbs through the provision of job opportunities and economic activities. Tourism development, in fact, enhances the quality of local physical development through a network of basic amenities and facilities that will be enhanced in order to meet the requirements of good tourism areas. Role of leaders and followers in the context of rural tourism is a must-have journey [20] that ensures the achievement of desired goals. As the local community leader is appointed officially by the government in a way to provide assistance and support rural tourism businesses and promotes followership by acting as a coordinating force for rural tourism development, there would be a greater enhancement in a way to sustain the local economy as a whole.

\section{ACKNOWLEDGMENT}

This paper is founded on the research project. Special appreciation is owed to Universiti Sultan Zainal Abidin (UniSZA) and Ministry of Education Malaysia for supporting this research.

\section{REFERENCES}

1. D. L. Edgell, Ten important world tourism issues for 2012. TRINET - Tourism Research Information Network List: 20th September. Available: www.timhawaii.edu/timlistserv.

2. E. W. George, H. Mair, and D. G. Reid, Rural tourism development: Localism and cultural change. Bristol: Channel View Publications, 2009.

3. H. Goodwin and R. Santilli, "Community-based tourism: A success?” ICRT Occasional Paper, 2009, pp. 1-37.

4. A. S. Hafis, A. Ramle, and I. Asmawi, "Influence of local leadership in poverty eradication among the Orang Asli communities in the state of Terengganu, Malaysia," Asian Social Science, 11(21), 2015, pp. 342-349.

5. L. Hiwasaki, E. Luna, and S. R. Syamsidik, Local and indigenous knowledge for community resilience: Hydro-meteorological disaster risk reduction and climate change adaptation in coastal and small island communities. Jakarta: UNESCO, 2014.

6. B. Lane, "Rural tourism: An overview," in SAGE Handbook of Tourism Studies, T. Jamal and M. Robinson, Eds. London: Sage Publications, 2009, pp. 354-370.

7. Malaysian Investment Development Authority (MIDA), Malaysia Investment Performance Report 2016. Kuala Lumpur: MIDA, 2017.

8. N. A. Halim, A. C. Er, J. H. Adam, M. A. A. Juhari, and S N. A. Tarmidzi, "Potensi pelancongan di Matu-Daro, Sarawak: Persepsi komuniti lokal," Geografia-Malaysian Journal of Society and Space, 8(9), 2012, pp. 13-21.

9. N. A. K. Zaman, H. Ahmad, N. A. K. Zaman, E. A. Choy, H. Jusoh, Z. Sakawi, and A. Buang, "Tahap penglibatan penduduk dalam pembangunan pelancongan Putrajaya (The level of residents' participation in tourism development in Putrajaya)," Geografia-Malaysian Journal of Society and Space 10(8), 2014, pp. 114-123.

10. E. Okazaki, "A community-based tourism model: Its conception and use," Journal of Sustainable Tourism, 16(5), 2008, pp. 511-529.

11. B. Prideaux, Resort Destinations-Evolution, Management and Development. Oxford: 
Butterworth-Heinemann, 2009.

12. A. Poon, Tourism, Technology and Competitive Strategies. Oxford: CAB International, 1993.

13. The Scottish Parliament, 2002. Rural tourism. Available: https://archive.parliament.scot/business/committees/histo ric/x-rural/or-02/ra02-2902.htm.

14. Economic Planning Unit (EPU), Rural development report. Kuala Lumpur: Prime Ministers Department Malaysia, 2016.

15. Tourism Malaysia, Press release. Putrajaya: Ministry of Tourism Malaysia, 2016.

16. V. Dukic, I. Volic, S. Tisma, and D. A. Jelincic, "Responsible community based ecotourism initiatives in protected rural areas of the Balkans: Case studies from Serbia and Croatia," American Journal of Tourism Management 3(1), 2014, pp. 51-63.

17. B. Weiler and C. M. Hall, Special Interest Tourism. London: Belhaven Press, 1992.

18. I. Yahaya, Pembangunan Pelancongan dan Perubahan Komuniti. Kuala Lumpur" Dewan Bahasa dan Pustaka, 2008.

19. J. W. Creswell, Steps in conducting a scholarly mixed methods study. Available: https://digitalcommons.unl.edu/cgi/viewcontent.cgi?articl $\mathrm{e}=1047 \&$ context $=$ dberspeakers .

20. C. Haven-Tang and E. Jones, "Local leadership for rural tourism development: A case study of Adventa, Monmouthshire, UK," Tourism Management Perspectives, 4, 2012, pp. 28-35.

21. Mabis, Evaluation Report. Aberystwyth: Mabis, 2008.

22. J. R. B. Ritchie and G. I. Crouch, The Competitive Destination: A Sustainable Tourism Perspective. Oxon: Cabi Publishing, 2003. 